\title{
On the homology of the frontal head pore in Cladocera (Crustacea: Branchiopoda)
}

\begin{abstract}
Alexey A. Kotov
A.N. Severtsov Institute of Ecology and Evolution, Leninsky Prospect 33, Moscow 119071, Russia. e-mail: alexey-a-kotov@yandex.ru
\end{abstract}

ABSTRACT: A frontal head pore is found in all representatives of the order Anomopoda (Cladocera) except for three genera: Daphnia O.F. Müller, 1785 (Daphniidae), Moinodaphnia Herrick, 1884 and Moina Baird, 1850 (Moinidae). It is also found in a representative of the order Onychopoda in the genus Polyphemus O.F. Müller, 1785. Earlier, this structure was detected in a few representatives of the orders Ctenopoda (Penilia Dana, 1852) and Haplopoda (Leptodora Lilljeborg, 1861). The presence of such a pore is a plesiomorphy of the Cladocera. The frontal head pore in the Cladocera and the Cyclestherida (Cladoceromorpha) is homologous to a pore in "Conchostraca" and Notostraca, which is the opening of a duct connecting the eye chamber with the environment, although its connection with the eye capsule in the Cladocera is not confirmed. The function of this pore is unknown, however a duct running into the head from the former, in the cladocerans and "conchostracans" obviously involves the ocellus and the frontal organ. Though poorly studied, the latter has a sensory function, which could suggest a participation of the frontal head pore in these functions.

How to cite this article: Kotov A.A. 2013. On the homology of the frontal head pore in Cladocera (Crustacea: Branchiopoda) // Invert. Zool. Vol.10. No.2. P.281-290.

KEY WORDS: Cladocera, Cladoceromorpha, functional morphology, morphological evolution, homology, frontal head pore.

\section{О гомологии фронтальной головной поры y Cladocera (Crustacea: Branchiopoda)}

\begin{abstract}
А. А. Котов
Институт проблем экологии и эволючии им. А. Н. Севериова РАН, Ленинский проспект, 33, Москва, 119071, Россия.

e-mail: alexey-a-kotov@yandex.ru

РЕЗЮМЕ: Фронтальная головная пора найдена у всех представителей отряда Anomopoda (Cladocera) за исключением только трех родов: Daphnia O.F. Müller, 1785 (Daphniidae), Moinodaphnia Herrick, 1884 и Moina Baird, 1850 (Moinidae). Также она присутствует у Polyphemus O.F. Müller, 1785 (Onychopoda). Ранее она была отмечена у представителей отрядов Ctenopoda (Penilia Dana, 1852) и Haplopoda (Leptodora Lilljeborg, 1861). Присутствие данной поры является синапоморфией Cladocera. Фронтальная головная пора у Cladocera и Cyclestherida (Cladoceromorpha) гомологична поре “Conchostraca” и Notostraca, являющейся протоком канала, соединяющего глазную камеру с окружающей средой, хотя связь этой поры с глазной капсулой
\end{abstract}


у кладоцер не подтверждена. Функция данной поры неизвестна, однако, канал от нее, идущий вглубь головы у кладоцер и “конхострак”, явно касается глазка и фронтального органа с плохо изученной сенсорной функцией, что может свидетельствовать об участии поры в последней путем обеспечения контакта с окружающей средой. Как цитировать эту статью: Kotov A.A. 2013. On the homology of the frontal head pore in Cladocera (Crustacea: Branchiopoda) // Invert. Zool. Vol.10. No.2. P.281-290.

КЛЮЧЕВЫЕ СЛОВА: Cladocera, Cladoceromorpha, морфология, морфологическая эволюция, гомология.

\section{Introduction}

The Cladocera (Crustacea: Branchiopoda) is a compact group of small-sized branchiopods containing four recent (Anomopoda Sars, 1865, Ctenopoda Sars, 1865, Onychopoda Sars, 1865 and Haplopoda Sars, 1865) orders and a single extinct (Cryptopoda Kotov, 2007) order. Each textbook on zoology or ecology contains basic information about the cladocerans, and it seems for a reader that this group is well-studied. But a non-specialist would be surprised to know that their morphology is studied quite poorly, first of all, because most efforts of the investigators have concentrated mostly on a single genus, Daphnia O.F. Müller, 1785. For some organs, no new information has been obtained since detailed observations of the 18 th-19th centuries. Due to this fact, any recent attempts to reconstruct a phylogeny of the Cladocera based on morphological characters (Olesen, 1998, 2000) are vulnerable to criticism (Fryer, 1999, 2002). There are some anatomical and morphological structures in the cladocerans with unknown function and even the presence-absence in different groups of the cladocerans of such structures is not confirmed. Specially interesting are dorsal head pores, which are intensively used in taxonomy, although their function is still unknown (Frey, 1959; Berner, 1987; Kotov, 1998; Dumont, Negrea, 2002). In the anomopod cladocerans some other types of pores are known: on the labrum and the limbs, connected to underlying glands that lubricate the limbs, and, in some genera, cuticular pores on the valves (Berner, 1987; Dumont, Silva-Briano, 1997; Dumont, Negrea, 2002).
Schödler (1846) was the first investigator who found a pore ventrally in the frontal portion of the head, near the bases of the antennae I, in the anomopod Acanthocercus rigidus Schödler, 1846 (now known as Acantholeberis curvirostris (O.F. Müller, 1776) — a member of the special family Acantholeberidae Smirnov sensu Dumont \& Silva-Briano, 1998). Subsequently, this "frontal head pore" was found in other families of the Anomopoda: in the bosminid Bosmina Baird, 1845 (Goulden, Frey, 1963; Koř́nek, 1971; Paggi, 1979), the daphniid Scapholeberis Schödler, 1858 and in Megafenestra Dumont \& Pensaert, 1983 (Dumont, Pensaert, 1983), Ceriodaphnia Dana, 1853 (Berner, 1987) and Simocephalus Schödler, 1858 (Alonso, 1996). Recently, scanning electron microscopy (SEM) became a very useful method to find and describe such structures. Using SEM, I found this structure in representatives of the two additional anomopod families (Kotov, 1996), the macrothricid Macrothrix laticornis (Jurine, 1820) and the eurycercid Eurycercus lamellatus (O.F. Müller, 1776). Subsequently, I reported the frontal head pore in many other anomopods, i.e., in many ilyocryptids (Kotov \& Štifter, 2006), bosminid Bosminopsis Richard, 1895 (Kotov, 1997), macrothricid Macrothrix elegans Sars, 1901 (Kotov et al., 2004), and chydorid Pleuroxus smirnovi Kotov, 2008 (Kotov, 1998, 2008), etc. It was also shown on SEM and discussed in alonine Leydigiopsis curvirostris Sars, 1901 by Van Damme (1998).

The frontal head pore was also detected in some representatives of the non-anomopod cladoceran orders, i.e. in the ctenopod Penilia avirostris Dana, 1852 (Meurice, 1981). The 
same pore was described in the adult haplopod Leptodora kindtii (Focke, 1844) by Akeret(1995), but the author erroneously considered this structure as the mouth. Subsequently, Korovchinsky and Boikova (2008) described this pore in $L$. kindtii, although the opinion of the authors about a bilobed structure seems hard to defend: it could be an artifact of fixation and preparation of the sample for SEM. Olesen et al. (2003) found the same pore in the embryo of Leptodora.

But until recently, there were no clear ideas on the presence-absence of the frontal head pore in the anomopods and other cladocerans. My aim was to make inventory of the presence of this structure in different anomopod cladocerans using SEM and to try to homologize it in the cladocerans and the large branchiopods.

\section{Material and methods}

SEM study of different species was the main source of information on determining presenceabsence of the frontal head pore. Specimens of different species were extracted from the samples that were preserved mainly in $4 \%$ formaldehyde. We apply lyophilisation for the preparation of specimens for SEM, but critical point drying can also be used (see Duigan, 1992). After the lyophilisation, the specimens were mounted on aluminum stubs, sputter coated with a thin layer

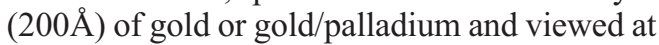
10 or $15 \mathrm{kV}$ using scanning electron microscope JEOL-840A or CAMSCAN MB 2300.

\section{Results}

The frontal head pore is found in all studied anomopods except for three genera: Daphnia O.F. Müller, 1785 (Daphniidae) (Fig. 1A), Moinodaphnia Herrick, 1884 and Moina Baird, 1850 (Moinidae). No pore was detected in Daphnia by researchers dealing with detailed anatomy of the eye and ocellus (Weismann, 18761879; Weiss et al., 2012). In Moina, only few representatives were investigated, therefore we are not sure about the absence of the pore in all species. In all other anomopods, the frontal head pore is located somewhat anteriorly near the bases of antenna I (Figs 1-3), which could suggest that it belongs to the preantennal head segment (Kotov, 1996).
The frontal head pore in different anomopods is represented by a ringed or non-ringed simple opening, or by a short longitudinal or (more frequently) transverse split. Sometimes (and even in different representatives of a single family) it has a different shape and a different position on the rostrum (if the latter is expressed). For example, in different species of the subgenus Bosmina (Liederobosmina) Brtek, 1997 it could be circular or semi-lunar and located on the frontal surface of the head, far from the antero-ventral margin, or on the ventral surface between the bases of antennae I (Paggi, 1979). Dumont \& Pensaert (1983) demonstrated that two genera of the subfamily Scapholeberinae Dumont \& Pensaert, 1983 (family Daphniidae) differ in the position of the frontal head pore.

We found that the position of the pore on the rostrum (if the latter is present) is variable, not only in the daphniids (Fig. 1C-D) and the bosminids, but also in the macrothricids (Fig. $1 \mathrm{G}-\mathrm{H}, 2 \mathrm{~A}-\mathrm{H})$ and their relatives, the Acantholeberidae (Fig. 1E) and Ophryoxidae (Fig. 1F) (now separated into special families, see Dumont \& Silva-Briano, 1998). In the genera Macrothrix Baird, 1843, Streblocerus Sars, 1862, Drepanothrix Sars, 1862, Bunops Birge, 1893, Grimaldina Richard, 1892, the frontal head pore is located on the dorsal side of the rostrum. In Streblocerus, the pore is located also on the dorsal surface of the head, very far from the bases of antennae I as compared with other genera. In contrast, in Guernella Richard, 1892 it is situated exactly on the ridge of the rostrum. In Acantholeberis Lilljeborg, 1853, Ophryoxus Sars, 1862, Neothrix Gurney, 1927, Lathonura Lilljeborg, 1853 and Wlassiscia Daday, 1903, the pore is located on the ventral surface of the head. In Neothrix, the rostrum is of "chydorid" appearance, and the pore is located anteriorly to the antenna I, being covered by the rostrum in frontal view. Therefore the position of the head pore could be used as a diagnostic character of macrothricid genera.

All eurycercids, bosminids and ilyocryptids have the frontal head pore (Fig. 3A-C).

In the chydorids, the anterior portion of the head shield is projected forward or ventral as a rostrum, and the frontal head pore is located in the region covered by the head shield from the top, and by antennae I and labrum from the bottom (Fig. 3D-H). Just due to this uncomfort- 

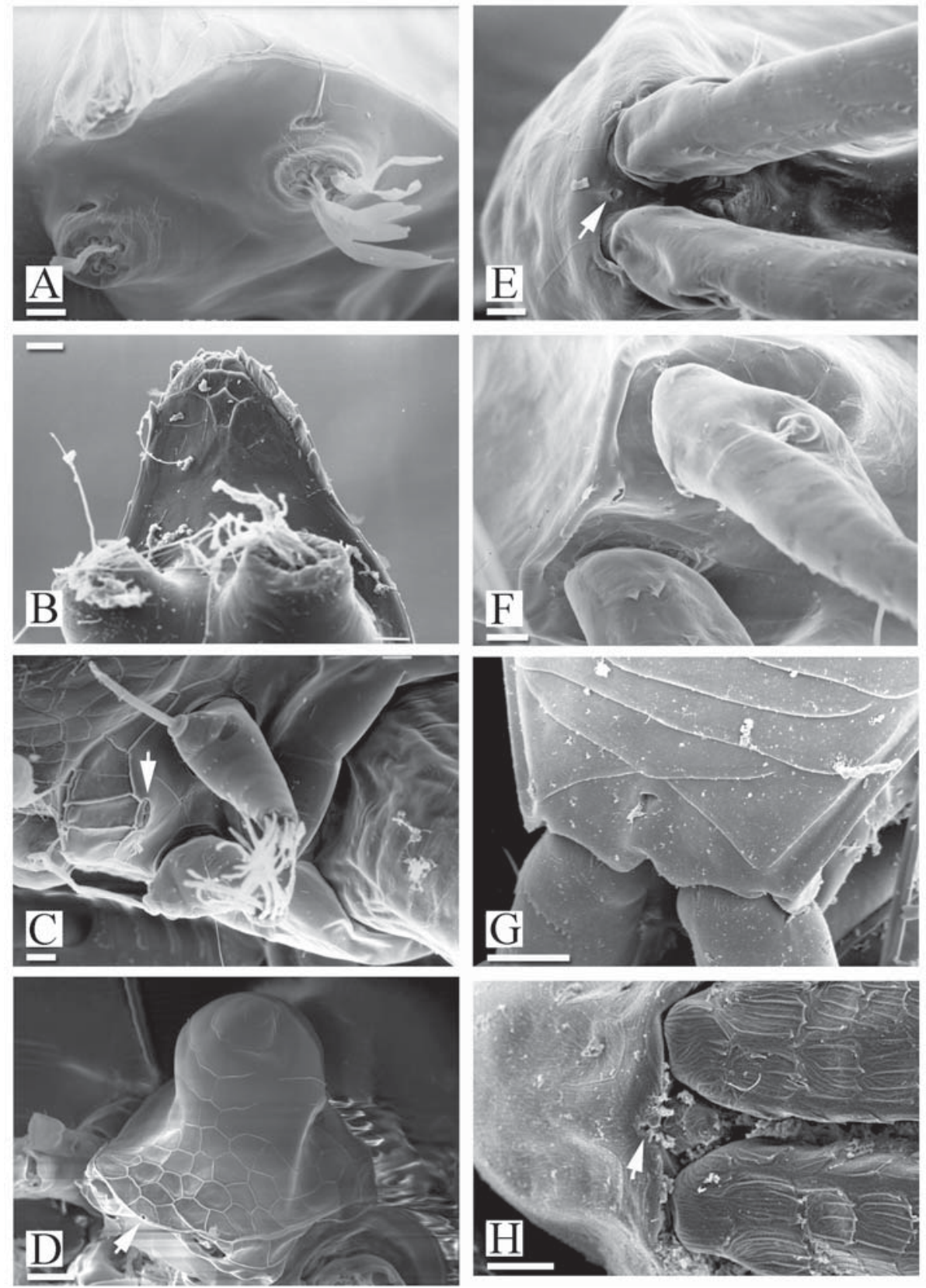

Fig. 1. Postero-ventral portion of head without frontal head pore in Daphniidae (A-B), and with one in other Daphniidae (C-D), Acantholeberidae (E), Ophryoxidae (F) and Macrothricidae (G-H) (marked by arrow). A - Daphnia pulex; B - D. magna; $\mathrm{C}$ - Simocephalus vetulus; $\mathrm{D}$-Scapholeberis microcephala $; \mathrm{E}$-Acantholeberis curvirostris; F — Ophryoxus gracilis; $\mathrm{G}$ - Grimaldina brazzai; H — Guernella raphaelis. Scale bar $0.01 \mathrm{~mm}$.

Рис. 1. Задне-нижняя часть головы без фронтальной головной поры у Daphniidae (A-B), и с фронтальной головной порой у других Daphniidae (C-D), Acantholeberidae (E), Ophryoxidae (F) and Macrothricidae (G-H) (пора указана стрелкой).

A - Daphnia pulex; B - D. magna; C - Simocephalus vetulus; D - Scapholeberis microcephala; $\mathrm{E}$ - Acantholeberis curvirostris; F - Ophryoxus gracilis; G — Grimaldina brazzai; H — Guernella raphaelis. Масштаб 0,01 мм. 

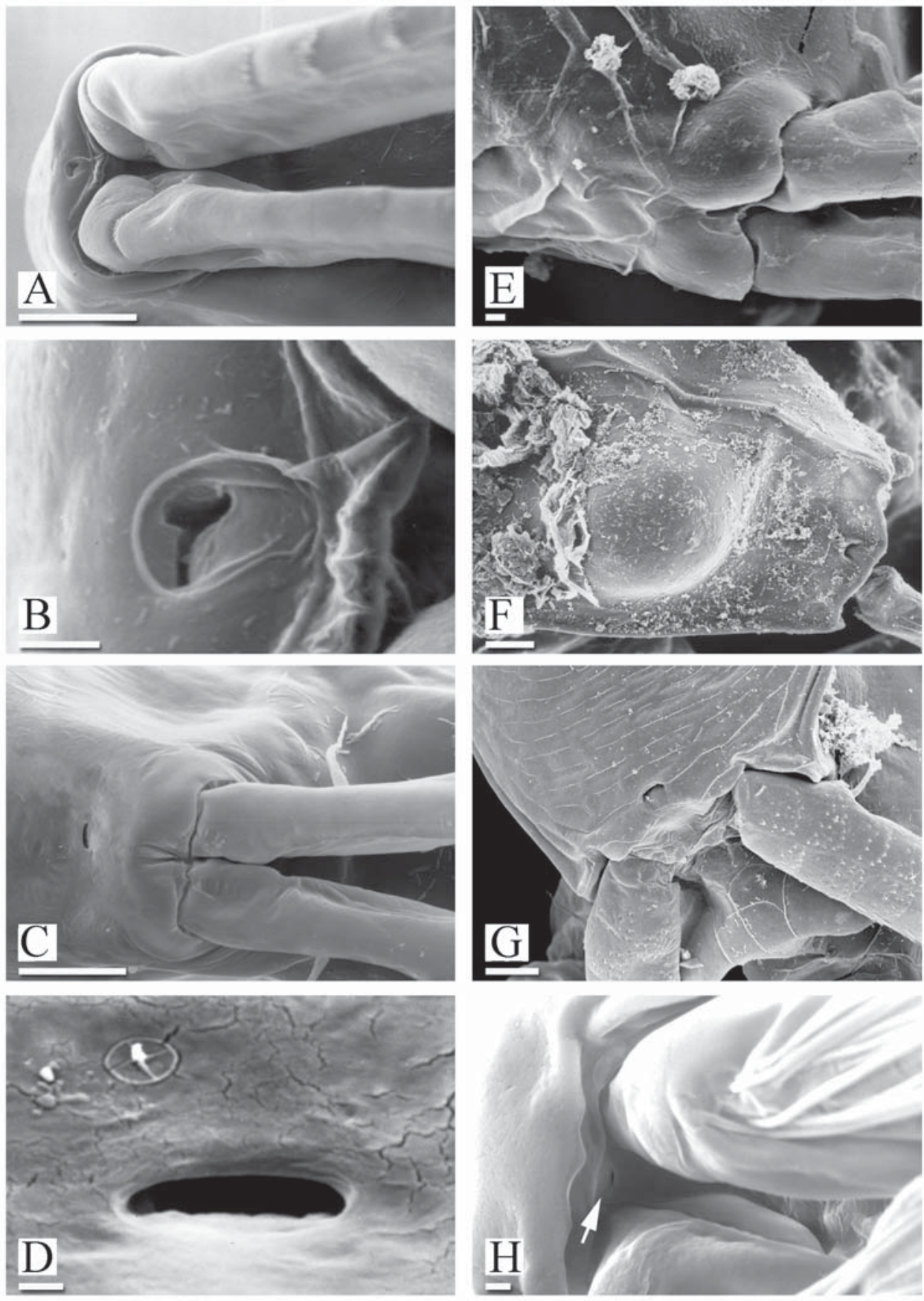

Fig. 2. Frontal head pore in different genera of Macrothricidae.

A-B - Drepanothrix dentata; C-D - Streblocerus serricaudatus; E - Streblocerus pygmaeus; F - Onchobunops tuberculatus; G - Wlassicsia pannonica; H - Neothrix armata. Scale bars: A, C, F-G - $0.01 \mathrm{~mm}$; B, D-E, H $-0.001 \mathrm{~mm}$. Рис. 2. Фронтальная головная пора у разных родов Macrothricidae.

A-B - Drepanothrix dentata; C-D - Streblocerus serricaudatus; E - Streblocerus pygmaeus; F - Onchobunops tuberculatus; $\mathrm{G}$ - Wlassicsia pannonica; $\mathrm{H}$ - Neothrix armata. Масштаб: A, C, F-G - 0,01 мм; B, D-E, H 0,001 мм. 
able position, the structure was rarely seen in many well-studied representatives of this family. I found that the frontal head pore is located in the chydorids somewhat anterior to the bases of antennae I and represented by a small transverse split.

I also found the frontal head pore in the onychopod Polyphemus pediculus (Linnaeus, 1761), but confirmed its absence in the large ctenopod Sida crystallina (O. F. Müller, 1776).

It is necessary to underline that I studied mainly females, and possible differences in the position of the frontal head pore between sexes need to be analyzed specially.

\section{Discussion}

To date, the frontal head pore is found in representatives of all four recent orders of the Cladocera. Among all cladocerans, especially examined for its presence, the pore is absent only in a few daphniids, moinids (order Anomopoda) and one sidid (order Ctenopoda). Definitively, the presence of this pore is a synplesiomorphy of the Cladocera, and its absence seems to be a result of secondary reduction.

To date, the existence of a monophyletic group Cladoceromorpha (Ax, 1999) is widely accepted, containing four recent cladoceran orders plus the order Cyclestherida (Olesen, 1998; Kotov, 2007). The Cyclestherida was earlier regarded as a member of the "Conchostraca", but the latter is accepted by all recent investigators as a paraphyletic group (Dumont, Negrea, 2002; Olesen, 2009). Two other former "conchostracan" orders, Spinicaudata and Laevicaudata, group together with the Cladoceromorpha into a monophyletic group Diplostraca Gerstaecker, 1868 = Onychura Erikson, 1934 = "conchostracan line" in Negrea et al., 1999). Below we will try to reconstruct the evolution of the frontal head pore in the conchostracanscladocerans.

It is widely accepted that in the evolutionary history of the Phyllopoda (Notostraca + "Conchostraca" + Cladocera), the paired stalked eyes first lost the stalks, became sedentary on the head surface, and then plunged to a special chamber within the head (Calman, 1909; Löppman, 1937). Such internalized eyes are regarded as an important synapomorphy of the Phyllopoda (Olesen, 2009). In Notostraca and Spinicau- data there is a wide pore, or special narrow duct connecting the chamber with a pair of sedentary eyes with the environment (Nowikoff, 1905ab; Wagler, 1927; Martin, 1992) (Fig. 5A-B). Cyclestherids have already a single, fused eye, similar to the situation in the Cladocerans (Olesen et al., 1996). They bear a pore in the anterodorsal portion of the head, which is to my opinion a homologue of the frontal head pore in the cladocerans. Sars (1887, Pl. III, Fig. 5) illustrated a duct passing from this pore to the region of the compound eye (Fig. 5C). Reimann and Richter (2007) wrote that this canal "connects the 'compound eye chamber' with the surface of the head via the eye pore". Earlier it was demonstrated that there is a similar duct in the anomopods, going from the frontal pore to the ocellus, brain ganglion or its vicinity (Kořínek, 1971; Dumont, Pensaert, 1983) (Fig. 5D). A hyalin secretory tissue was detected in this area on TEM photos in Bosmina (Havel, 1978), but no physiological explanations were suggested.

Although the connection of the eye capsule with the environment is not confirmed in the cladocerans, a homology of the frontal head pore and the pore connecting the eye cavity with the environment in the "conchostracans" is obvious. A remarkable fact is that in the notostracans and "conchostracans" (but not in Cyclestherids!) a duct going from the head pore to eye capsule touches the naupliar eye and frontal organ (Nowikoff, 1905a-b; Calman, 1909; Martin, 1992). Similarly, in the cladocerans, the duct from the frontal head pore touches the ocellus (Dumont, Pensaert, 1983) — a derivate of the naupliar eye, although probably there is no connection with the eye chamber (in the cladocerans called "eye capsule").

Although the naupliar eye and the frontal organ in the Branchiopoda are intensively studied (Reimann, Richter, 2007; Fritsch, Richter, 2010; Fritsch et al., 2013), their function still is "not well known" (Dumont, Negrea, 2002), in particular there are problems in the homologization of such a functional complex in the Branchiopoda and other Crustacea (Elofsson, 1966, 2006). The function of the head pore and the aforementioned duct is also unknown, but their association with the eye chamber or/and frontal organ may suggest a participation in sensory function, i.e. providing a connection with the outside environment. 

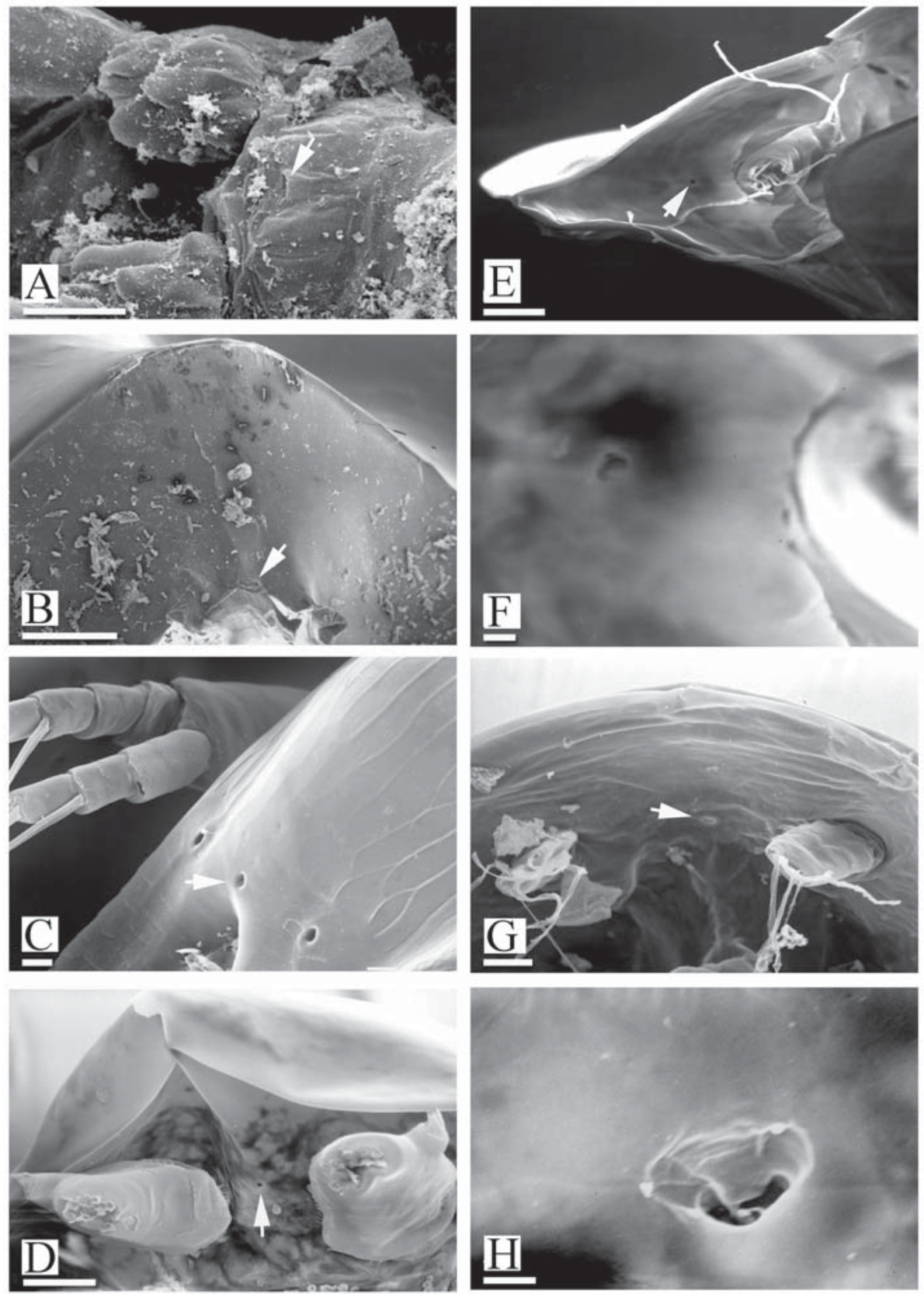

Fig. 3. Frontal head pore in Ilyocryptidae (A), Eurycercidae (B), Bosminidae (C) and Chydoridae (D-H) (marked by arrow).

A - Ilyocryptus gouldeni; B - Eurycercus lamellatus; C - Bosmina longispina; D - Euryalona orientalis; E-F Acroperus harpae; G-H - Graptoleberis testudinaria. Scale bars: B-E, G-0.01 mm; A, F, H $-0.001 \mathrm{~mm}$.

Рис. 3. Фронтальная головная пора у Ilyocryptidae (A), Eurycercidae (B), Bosminidae (C) и Chydoridae (D-H) (пора указана стрелкой).

A - Ilyocryptus gouldeni; B - Eurycercus lamellatus; C - Bosmina longispina; D - Euryalona orientalis; E-F Acroperus harpae; G-H - Graptoleberis testudinaria. Масштаб: B-E, G-0,01 мм; A, F, H - 0,001 мм. 

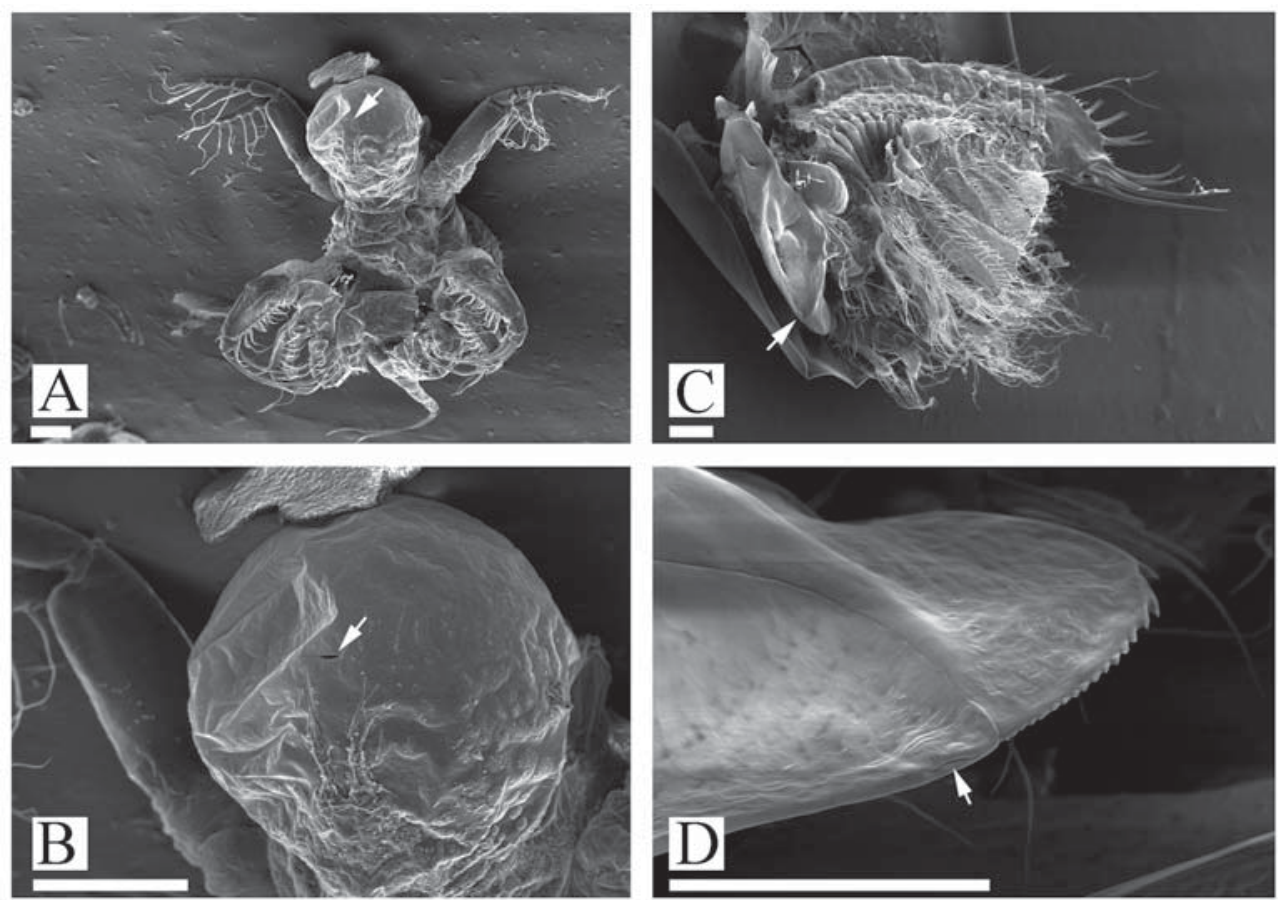

Fig. 4. Frontal head pore in Onychopoda (A-B) and Cyclestherida (C-D).

A-B - Polyphemus pediculus; C-D - Cyclestheria hislopi. Scale bar $0.1 \mathrm{~mm}$.

Рис. 4. Фронтальная головная пора у Onychopoda (A-B) и Cyclestherida (C-D).

A-B - Polyphemus pediculus; C-D - Cyclestheria hislopi. Масштаб 0,1 мм.

The "rostral" pore (or analogous sensory structures) is found in other crustaceans, i.e. in the copepods (Boxshall, 1982; Oldewage, Van As, 1989), where the former is a part of a very complicated system of the pores on the cephalon. There is a large pore in the center of rostral zone in the syphonostomatid copepods (Ivanenko, Smurov, 1997). Also the phyllopod frontal head pore connecting the eye chamber with the environment could be regarded as a very distant analogue to sensory pores connecting the eyes to the outside world in Malacostraca (Elofsson, 1963; Chaigneau, 1973). But all aforementioned pores definitively have other origins and are not homologous to the cladoceran frontal head pore.

\section{Acknowledgements}

I am grateful to Prof. N.N. Smirnov, Prof. H.J. Dumont and Dr K. Van Damme for valuable comments and linguistic corrections. The study is supported by the Russian Foundation for Basic Research grant \# 12-04-00207-a and the "Biodiversity" Program of the Presidium of Russian Academy of Sciences.

\section{References}

Akeret B. 1995. Specific density of resting eggs and adult morphology of Leptodora kindtii (Focke, 1844) (Cladocera) // Crustaceana. Vol.68. P.751-758.

Alonso M. 1996. Crustacea, Branchiopoda. Fauna Iberica 7. Crustacea Branchiopoda. Madrid: Consejo Superior de Investigaciones Cientificas. $486 \mathrm{pp}$.

Ax P. 1999. Das System der Metazoa II. Ein Lehrbuch der phylogenetischen Systematik. Mainz: G. Fischer. 283 S.

Berner D.B. 1987. Significance of head and carapace pores in Ceriodaphnia (Crustacea, Cladocera) // Hydrobiologia. Vol.145. P.75-84.

Boxshall G.A. 1982. On the anatomy of the misophrioid copepods, with special reference to Benthomisophria palliata//Phil. Trans. R. Soc. London. Ser.B. Vol.297. P.125-181.

Calman W.T. 1909. Chapter 2. The Branchiopoda // Lankester R. (ed.). A Treatise on Zoology. Part VI. Appendiculata. Third Fascicle: Crustacea. London: Adam and Charles Black. P.29-51.

Chaigneau J. 1973. Fine structure of the sensory pore present in the eyestalk of Crustacea Natantia // Z. Zellforsch. Vol.145. P.213-227.

Duigan C.A. 1992. The ecology and distribution of the littoral freshwater Chydoridae (Branchiopoda, Anomopoda) of Ireland, with taxonomic comments on some species // Hydrobiologia. Vol.241. P.1-70. 

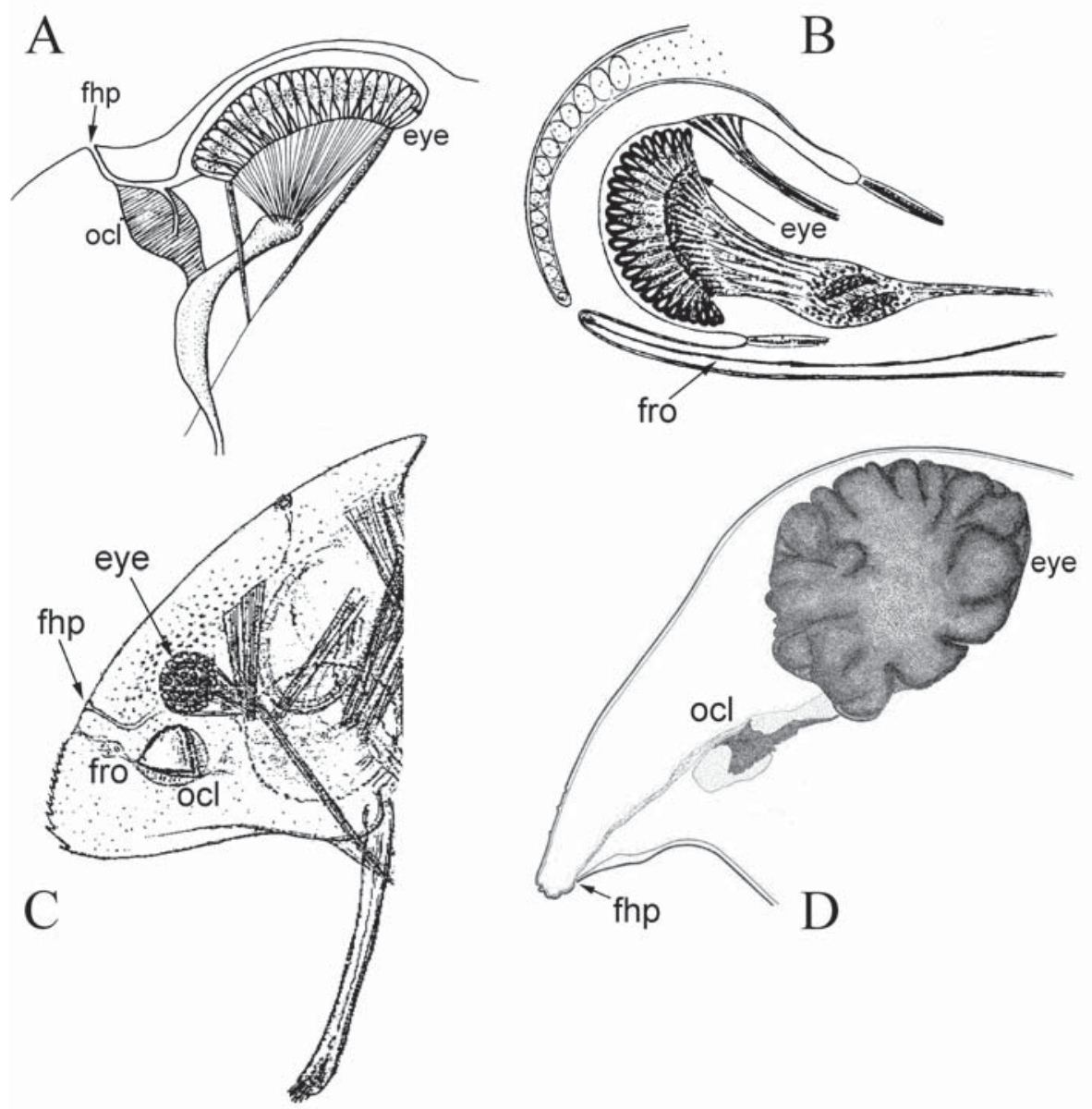

Fig. 5. Frontal head pore in the Branchiopoda.

A - Triops sp. (Notostraca) (after Calman, 1909); B - Limnadia lenticularis (Spinicaudata) (after Nowikoff, 1905a); C - Cyclestheria hislopi (Cyclestherida) (after Sars, 1887); D - Megafenestra aurita (Anomopoda: Daphniidae) (after Dumont, Pensaert, 1983).

Рис. 5. Фронтальная головная пора у Branchiopoda.

A - Triops sp. (Notostraca) (по: Calman, 1909); В — Limnadia lenticularis (Spinicaudata) (по: Nowikoff, 1905a); C - Cyclestheria hislopi (Cyclestherida) (по: Sars, 1887); D — Megafenestra aurita (Anomopoda: Daphniidae) (по: Dumont, Pensaert, 1983).

Dumont H. J., Negrea S.V. 2002. Introduction to the class Branchiopoda // Dumont H.J. (ed.). Guides to the identification of the microinvertebrates of the continental waters of the world. Leiden: Backhuys Publishers. Vol.19. 398 p.

Dumont H.J., Pensaert J. 1983. A revision of the Scapholeberinae (Crustacea: Cladocera) // Hydrobiologia. Vol.100. P.3-45.

Dumont H.J., Silva-Briano M. 1997. Sensory and glandular equipment of the trunk limbs of the Chydoridae and Macrothricidae (Crustacea: Anomopoda) // Hydrobiologia. Vol.360. P.33-46.

Dumont H.J., Silva-Briano M. 1998. A reclassification of the anomopod families Macrothricidae and Chydoridae, with the creation of a new suborder, the
Radopoda (Crustacea: Branchiopoda) // Hydrobiologia. Vol.384. P.119-149.

Elofsson R. 1963. The nauplius eye and frontal organs in Decapoda (Crustacea) // Sarsia. Vol.12. P.1-68.

Elofsson R. 1966. The nauplius eye and frontal organ of the non-malacostraca (Crustacea) // Sarsia. Vol.25. P.1-128.

Elofsson R. 2006. The frontal eyes of crustaceans // Arthropod Struct. Dev. Vol.35. P.275-291.

Frey D.G. 1959. The taxonomic and phylogenetic significance of the head pores of the Chydoridae (Cladocera) // Int. Rev. ges. Hydrobiol. Vol.44. P.27-50.

Fritsch M., Richter S. 2010. The formation of the nervous system during larval development in Triops cancrifor- 
mis (Bosc) (Crustacea, Branchiopoda): an immunohistochemical survey // J. Morphol. Vol.271. P.1457-1481.

Fritsch M., Kaji T., Olesen J., Richter S. 2013. The development of the nervous system in Laevicaudata (Crustacea, Branchiopoda): insights into the evolution and homologies of branchiopod limbs and 'frontal organs'// Zoomorphology. DOI 10.1007/s00435-012-0173-0

Fryer G. 1999. A comment on a recent phylogenetic analysis of certain orders of the branchiopod crustacea // Crustaceana. Vol.72. P.1039-1050.

Fryer G. 2002. Branchiopod phylogeny: Facing the facts // Crustaceana. Vol.75. P.85-88.

Goulden C.E., Frey D.G. 1963. The ocurrence and significance of lateral head pores in the genus Bosmina (Cladocera) // Internat. Rev. ges. Hydrobiol. Hydrograph. Vol.48. P.513-522.

Havel L. 1978. Ultrastruktura a taxonomický význam hlavových pórů rodu Bosmina -(Cladocera). Rigorosní práce. Praha: Hydrobiol. Lab.Botan. Ústav CSAV. 63 p.

Ivanenko V.N., Smurov A.V. 1997. Asterocheres flustrae n. sp. (Copepoda: Siphonostomatoida: Asterocheridae) associated with Flustra foliacea (L.) (Bryozoa) from the White Sea // Syst. Parasitol. Vol.38. P.111-130.

Kořínek V. 1971. Comparative study of head pores in the genus Bosmina Baird (Crustacea, Cladocera) // Věst. Ćesk. Společ. Zool. Vol.35. P.275-296.

Korovchinsky N.M., Boikova O.S. 2008. Study of the external morphology of Leptodora kindtii Focke, 1844 (Crustacea: Branchiopoda: Haplopoda), with notes on its relation to Cladocera and on conspecificity of populations of the species over the Eurasian range // J. Nat. Hist. Vol.42. P.2825-2863.

Kotov A.A. 1996. [Frontal head pore in primitive representatives of families Chydoridae and Macrothricidae (Anomopoda, Crustacea)] // Zool. Zhurn. Vol.75. P.1603-1607 [in Russian, with English summary].

Kotov A.A. 1997. Studies on the morphology and variability of Amazonian Bosminopsis deitersi Richard, 1895 (Anomopoda Bosminidae) // Arthropoda Selecta. Vol.6. No.1-2. P.3-30.

Kotov A.A. 1998. [A comparative analysis of morphology of the Anomopoda (Crustacea, Branchiopoda)]. [Autoreferate of the Thesis of Candidate (Ph.D.) of Biological Sci. Degree]. Moscow: A.N. Severtsov Institute of Ecology and Evolution. 309 pp. [in Russian]

Kotov A.A. 2008. Finding of Pleuroxus smirnovi sp. nov. from the Pamir region revealed today's imperfect state of systematics and biogeography of the Chydorinae (Cladocera: Chydoridae)//Int. Rev. Hydrobiol. Vol.93. P.200-209.

Kotov A.A., Garfias-Espejo T., Elías-Gutiérrez M. 2004. Separation of two Neotropical species: Macrothrix superaculeata (Smirnov, 1982) versus M. elegans Sars, 1901 (Macrothricidae, Anomopoda, Cladocera) // Hydrobiologia. Vol.517. P.61-88.

Kotov A.A., Štifter P. 2006. Cladocera: family Ilyocryptidae (Branchiopoda: Cladocera: Anomopoda) // Dumont H.J. (ed.). Guides to the identification of the microivertebrates of the Continental Waters of the world. Ghent: Kenobi Productions, Leiden: Backhuys Publishers. Vol.22. 172 p.

Löpmann A. 1937. Die Zweiaugigkeit von Diaphanosoma (Zugleich ein Beitrag zur Kenntnis des Cladocerenauges)//Int. Rev. ges. Hydrobiol. Hydrograph. Bd.34. P.432-487.
Martin J.W. 1992. Branchiopoda // Harrison F., Humes A.G. (eds.). Microscopic Anatomy of Invertebrates. 9. Crustacea. New York: Wiley-Liss, Inc. P.25-224.

Meurice J.Cl. 1981. Aspects morphologiques au microscope électronique á balayage d'un Cladocere marine colyptomere: Penilia avirostris Dana.// Rapp. Proc. Verb. Reum. Comis. Int. Explor. Sci. Mer. Méditerr. Monaco. T.2. P.161-162.

Negrea S., Botnariuc N., Dumont H.J. 1999. Phylogeny, evolution and classification of the Branchiopoda (Crustacea) // Hydrobiologia. Vol.412. P.191-212.

Nowikoff M. 1905a. Über die Augen und die Frontalorgane der Branchiopoden // Z. Wiss. Zool. Bd.79. S.432-464.

Nowikoff M. 1905b. Untersuchungen über den bau der Limnadia lenticularis L. // Z. Wiss. Zool. Bd.78. S.561-619.

Oldewage W.H., Van As J.G. 1989. On the sensory (?) structure between the frontal plates of Caligus O.F. Müller, 1785 (Copepoda, Caligidae) // Crustaceana. Vol.57. P.72-78.

Olesen J. 1998. A phylogenetic analysis of the Conchostraca and Cladocera (Crustacea, Branchiopoda, Diplostraca) // Zool. J. Linn. Soc. Vol.122. P.491-536.

Olesen J. 2000. An updated phylogeny of the Conchostraca-Cladocera clade (Branchiopoda, Diplostraca) // Crustaceana. Vol.73. P.869-886.

Olesen J. 2009. Phylogeny of Branchiopoda (Crustacea) Character evolution and contribution of uniquely preserved fossils // Arthropod Syst. Phyl. Vol.67. P.3-39.

Olesen J., Martin J.W., Roessler E.W. 1996. External morphology of the male of Cyclestheria hislopi (Baird, 1859) (Crustacea, Branchiopoda, Spinicaudata), with a comparison of male claspers among the Conchostraca and Cladocera and its bearing on phylogeny of the 'bivalved' Branchiopoda // Zool. Scr. Vol.25. P.291-316.

Olesen J., Richter S., Scholtz G. 2003. On the ontogeny of Leptodora kindtii (Crustacea, Branchiopoda, Cladocera), with notes on the phylogeny of the Cladocera // J. Morphol. Vol.256. P.235-259.

Paggi J.C. 1979. Revision de las especies argentinas del genero Bosmina Baird agrupodas en el subgenero Neobosmina Lieder (Crustacea, Cladocera) // Acta Zool. Lill. Vol.35. P.137-162.

Reimann A., Richter S. 2007. The nauplius eye complex in 'conchostracans' (Crustacea, Branchiopoda: Laevicaudata, Spinicaudata, Cyclestherida) and its phylogenetic implications // Arth. Struct. Devel. Vol.36. P.408-419.

Sars G.O. 1887. On Cyclesheria hislopi (Baird), a new generic type of bivalve Phyllopoda, raised from Australian mud // Forh. Vidensk.-Selsk. Krist. Nr.1. P.223-239.

Van Damme K. 1998. Conchostraca and 'Cladocera' (Crustacea) of dune pools in the Lençóis Maranhenses, NEBrazil. Ms. Sci. Thesis. Ghent: The State University of Ghent. 179 pp.

Wagler E. 1927. Branchiopoda, Phyllopoda $=$ Kiemenfüsser // Kükenthal W. (Hrsg.). Handbuch der Zoologie. Bd.3B. No.1. S.305-398.

Weismann A. 1876-1879. Beiträge zur Naturgeschichte der Daphnoiden // Z. wiss Zool. Bd.27-33. S.1-486.

Weiss L.C., Tollrian R., Herbert Z., Laforsch C. 2012. Morphology of the Daphnia nervous system: A comparative study on Daphnia pulex, Daphnia lumholtzi, and Daphnia longicephala // J. Morphol. Vol.273. P.1392-405.

Responsible editors A.Yu. Sinev, E.N Temereva, K.G. Mikhailov 